\title{
A dearth of evidence: tackling division and building relationships in Northern Ireland
}

Kelly, G., \& Braniff, M. (2016). A dearth of evidence: tackling division and building relationships in Northern Ireland. International Peacekeeping, 23(3), 442-467. https://doi.org/10.1080/13533312.2016.1166962

Link to publication record in Ulster University Research Portal

\author{
Published in: \\ International Peacekeeping
}

Publication Status:

Published (in print/issue): 26/05/2016

DOI:

10.1080/13533312.2016.1166962

\section{Document Version}

Author Accepted version

\section{General rights}

Copyright for the publications made accessible via Ulster University's Research Portal is retained by the author(s) and / or other copyright owners and it is a condition of accessing these publications that users recognise and abide by the legal requirements associated with these rights.

\section{Take down policy}

The Research Portal is Ulster University's institutional repository that provides access to Ulster's research outputs. Every effort has been made to ensure that content in the Research Portal does not infringe any person's rights, or applicable UK laws. If you discover content in the Research Portal that you believe breaches copyright or violates any law, please contact pure-support@ulster.ac.uk. 
This is an Accepted Manuscript of an article published by Taylor \& Francis in International Peacekeeping on 11/04/2016, available online:

http://www.tandfonline.com/doi/full/10.1080/13533312.2016.1166962.

\section{A Dearth of Evidence: \\ Tackling Division and Building Relationships in Northern Ireland}

Authors:

Dr Maire Braniff

School of Sociology and Applied Social Studies

Ulster University

m.braniff@ulster.ac.uk

Ms Gráinne Kelly

INCORE

Ulster University

g.kelly@ulster.ac.uk

This research was funded by the Equality Directorate Research Branch of the Office of the First Minister and deputy First Minister, Northern Ireland Assembly, as part of the Delivering Social Change Research Programme. 
A Dearth of Evidence: Tackling Division and Building Relationships in Northern Ireland

\begin{abstract}
Addressing the estrangement of distinct identity groups as a result of violent conflict is one of the challenging and persistent socio-psychological peacebuilding imperatives in a post-accord context. In the immediacy of a peace agreement, priority is given to pressing security and institutional arrangements, particularly within the context of substantial external intervention. Northern Ireland represents an interesting case study, as particular attention was paid to the divisions between the two main communities. And yet, despite substantial economic investment, the detail of how these initiatives have been informed, designed and achieved have not been readily accessible. Focusing on grassroots-based relationship building, this article contends that the failure to document, analyze and adequately disseminate the approaches taken to address intercommunal division has resulted in community-level peacebuilding which is unnecessarily ad hoc and extemporary, and the focus on delivery has militated against cultures of learning, reflexivity and generosity in sharing of good practice.
\end{abstract}

Key Words: Peacebuilding, relationship-building, methodology, evaluation, grant-aid, social cohesion 


\section{Introduction}

When parties in conflict reach political agreement, the reality of securing and institutionalizing peace poses a stark challenge for both internal and external actors. With the immediate task of responding to a new set of security and political considerations, sufficient attention is seldom paid to the challenge of building intercommunal relationships in the most effective and resourceful way possible. Keeping the peace involved not only a cessation of violence, but the repairing of severely damaged relations between, and within, distinct communities of identity. This requires a longerterm shift in managing difference peacefully, and this, we contend, requires active intervention, rather than passive aspiration at both policy and practice levels. To ignore the value in attending to relationships, and to fail to interrogate the most successful approaches to building those relationships, is risky at best. The threat of re-emerging violence is high. According to the UN Secretary General, the success of mediating and implementing peace has been blemished by failures, which have seen 'roughly half of all countries that emerge from war lapse back into violence within five years. ${ }^{1}$ While there is substantive literature focusing on the how and why of peace agreement failure at socio-economic and political level, ${ }^{2}$ it is only more recently that 'local and micro-level dynamics' have been given serious consideration. ${ }^{3}$ As the figures suggest that the implementation of peace is both precarious and multivariate, it is essential to reflect upon cases where a relapse into significant levels of violence has been avoided. Northern Ireland is one such case where an historic peace agreement was reached in 1998 which has afforded a state of relative peace since. However, within this context, challenges prevail and the bedding in of the institutional arrangements does not represent the full picture of what is required to support the new security, political and socio-economic contexts. The Northern Ireland model of peacemaking and peacebuilding (and the key actors involved) has been espoused internationally in terms of ambition, persistence and design. However, the continued threats posed by paramilitary spoiler groups, and on-going inter-communal tensions and intermittent violence, put the new security and policing arrangements under serious strain and risks destabilization of the political arrangements. An exploration of how relationships are understood and built in Northern Ireland offers an opportunity for a more detailed appraisal of how good practices in peacebuilding are documented, shared and reflected upon. The lessons drawn from such endeavours provide donors, policy makers, practitioners, political leaders and, indeed, theorists, with a shared understanding of how challenging the delivery of micro-level process of peace at intra- and intercommunal levels.

This article adds to the underdeveloped scholarship that critiques and engages with contemporary models of how to peace is supported and maintained at community level, following political compromise. While focusing on Northern Ireland as a case example, this article argues that, with the growth in intra-state conflicts in the past decades, a 
more detailed analysis of the challenge of building greater levels of intercommunal trust and reciprocity is an issue for many societies emerging from violent conflict. The themes of methodology, documentation, reflexivity, monitoring and evaluation which will be explored here are transferable across different contexts. Twenty years on from the first paramilitary ceasefires which paved the way for the political agreement, we would argue that Northern Ireland has reached a key juncture from which an honest and critical appraisal of the successes and failures of peacebuilding interventions at community level should be possible. The value in documenting and sharing these considered reflections with other societies facing similar communal cleavages should be evident. The timeliness of this article is clear: Northern Ireland, as a peacebuilding model, reveals a lacuna in how we approach aspects of peacebuilding, both in terms of scholarship and practice. The findings of this study challenge the assumptions of the effectiveness of community-based peacebuilding, the expectations of external donors, and the capacity for peace practitioners to develop positive interventions which can be transposed to other contexts, based on well-supported evidence of success.

Following over thirty years of violence, involving both state and paramilitary actors, and nearly twenty years on from the peace accord, Northern Ireland remains a highly segregated society, residentially, educationally and socially. The physical and psychological estrangement of the Catholic/Nationalist/Republican and Protestant/Unionist/Loyalist communities has not significantly altered since the ceasefires of 1994, indicating that the deep entrenchment of segregation and sectarianism in the society is not easily unraveled. The increase in the number and height of 'peace walls' dividing communities of identity in urban areas, ${ }^{4}$ the segregated school systems in which 93 per cent of pupils are educated separately, ${ }^{5}$ the continued paramilitarism and associated criminality, ${ }^{6}$ and the ongoing volatility over the expression of cultural identity in the form of flags and parades protests, ${ }^{7}$ all point to the challenges facing those who seek to build sustainable relationships and work to promote and encourage a 'shared future' for future generations.

Since 1987, an estimated four billion dollars ${ }^{8}$ in peace-focused grant aid has been spent in Northern Ireland, the majority of which has been directed towards the region's civil society and local government sectors. This funding has been made available through international donors such as the European Union, Atlantic Philanthropies and the International Fund for Ireland, as well as local grantmakers such as the Northern Ireland Community Relations Council (NICRC) and the Community Foundation for Northern Ireland, both of which have administered substantial grant programmes on behalf of philanthropic and government funding sources. Given this decades-long economic and social investment, one might confidently argue that a substantive intellectual store of knowledge regarding effective practice in addressing the realities of segregation and sectarianism has been built up by those engaged in 'community relations', 'good relations', 'peacebuilding' and 'reconciliation', as it is variously labelled. For example, between 1995 and 2007, over 21,000 applications for funding were approved by the European Union Peace and Reconciliation Fund. ${ }^{9}$ From 1986 to 2010, the International 
Fund for Ireland has supported over 6,200 individual projects. ${ }^{10}$ In 2012-13 alone, the NICRC provided grant aid of 2.79 million pounds to support 279 'community relations' projects. ${ }^{11}$ Given the region's 1.8 million population, and the potential reach and impact of supported interventions, these figures are impressive.

Addressing fear and the threat of violence, addressing fractured relationships, building bridges between communities, promoting cultural diversity and dealing with the legacies of the past have been the main strategies for community-based peacebuilding in Northern Ireland. Yet, as Power points out, "the fact that there is no definitive way of measuring the impact and effectiveness of this work, means that its usefulness will always be under question". ${ }^{12}$ Funding and delivering processes aimed at promoting greater cohesion between divided communities has operated under the primary assumption that to bring people together, to affect either attitudinal or behavioural change, is a significant contribution to the overall peacebuilding agenda. Focusing on the nature of grant-aid in support of such assumptions, a key starting point for this article is the reflection by Anderson and Olsen that "all the good peace work being done should be adding up to more than it is. The potential of these multiple efforts is not realised". ${ }^{13}$ In an effort to open a wider debate on the methodology-impact-evaluation loop, which should include practitioners, funders, and researchers alike, we reiterate their follow up question: "How do we know that the work we do for peace is worthwhile?"14

Despite the high levels of activity and intervention at community-level in Northern Ireland, there is increasing evidence to indicate that the vital work of documenting and disseminating effective practice is often missed, not given enough attention or simply by-passed. ${ }^{15}$ Building on desk-based research, this article has four key foci. Firstly, it explores the international conflict resolution and peacebuilding literature on the purpose and utility of documenting and evaluating methodological practices. Secondly, it reviews the existing academic and practitioner-focused literature, which goes some way to document a range of interventions to support relationship-building work in Northern Ireland. It then goes on to present the findings of a sample search for grey literature which details the approaches adopted by key organizations involved in the delivery of community relations objectives, to uncover the extent to which they exist or are disseminated. Finally, it reflects on the relative dearth of materials and on the consequences of such a deficit for the future of 'good relations' work in Northern Ireland and other societies seeking to tackle inter-communal and inter-ethnic tensions, estrangement and violence.

\section{Micro-level Peacebuilding: Informed and Effective?}

Reaching political agreement between warring parties has long been a focus of international scholarship, which has provided analysis on the cut and thrust of elite level peace making and building. The inter-disciplinary fields of international relations, comparative political science and, more recently, peace and conflict studies, have a long 
history of documentation and analysis of the role of political and military leadership in the resolution of inter- and intra-state conflicts. It is only more recently, however, that an identifiable body of literature has emerged which focuses on the role of civil society in peacebuilding and reconciliation processes. John-Paul Lederach's three-tiered approach to building peace places emphasis on the crucial role played by grassroots leadership - including those in the non-governmental sector. ${ }^{16}$ Lederach notes that, unlike the elite political leadership, 'grassroots leaders witness firsthand the deeprooted hatred and animosity on a daily basis ${ }^{17}$ and, as such, have a strategic role to play in delivering on the key tasks of relationship-building and reconciliation between estranged parties. This, more broadly-based conflict transformation approach proposed has become increasingly influential, but the extent to which it has been effectively implemented requires further investigation. ${ }^{18}$ Paffenholz unpacks the challenge of understanding civil society's role in peacebuilding both conceptually and practically, and the extent to which civil society can be credited with making a significant contribution to societal change, given the current 'deficit of theories'. ${ }^{19}$ She notes that, from the late 1990s, there has been a perceptible and growing reluctance of donors to support civil society initiatives that fail to demonstrate a positive impact on wider peace processes. Her research indicates that many interventions have made claims of long-term impact which they cannot substantiate with specific results. ${ }^{20}$ The points offered by Paffenholz start to carve a niche in the previously impenetrable model of 'peace through funding' and highlights a central area for debate as we move to contemplate how to keep the peace in a range of post-Cold War, post-agreement societies.

The process of defining, documenting and analyzing the successes and failures of peacebuilding initiatives requires both a clear understanding of the core objectives of the intervention, as well as a pragmatic view of the wider contextual challenges which impact on the ability of any process to make significant change. Smith and Smock propose that metrics or measurable indicators of progress could assist the formulation and patterns of change following a peace agreement. ${ }^{21}$ Such baseline indicators preand immediately after an agreement therefore permit the tracking of progress throughout the post-agreement period. Collecting data for analysis and lessons learned from past and on-going peacebuilding initiatives could provide a corpus of useable knowledge which can continue to inform the specific context under focus, as well as current and future contexts which can learn from such information. This reminds us that the immediacy of efforts at keeping the peace are not simply confined to security and stabilization, but rather extend into debates about how financial and technical assistance is used, maximized and reflected upon.

The increased focus on monitoring and evaluation in peacekeeping and peacebuilding interventions over the past two decades ${ }^{22}$ has highlighted the importance of critiquing both the theory of change underpinning them, at all levels, as well as the practical methodological approaches adopted to create positive difference. This move towards more reflective scholarship denotes a shift in concern from fire-fighting to understanding why, and how things, work. Weiss ${ }^{23}$ popularized the term theory of 
change', which articulates both the how and the why of an initiatives' goal, activities and outcomes. This approach was extended by Connell and Kubisch to define evaluation of community work more broadly as a 'systematic and cumulative study of the links between activities, outcomes, and contexts of the initiative'. ${ }^{24}$ They go on to stress the merits of evaluation, affirming it as a "powerful tool for promoting collaboration and engagement", in addition to aiding problem-solving in the field. Writing from the perspective of post-conflict peacebuilding, Menkhaus argues that "project evaluation and impact assessments take on added significance, not merely as a tool insuring accountability to donors and as a mechanism with which to derive lessons learned, but as a means of testing the credibility of the entire approach". ${ }^{25}$

Compiling documented appraisal of ones' own work has tended not to be emphasized within deeply divided societies attempting to offset inter-communal segregation and legacies of violent conflict. Verkoren makes a pragmatic argument about the limits of this possibility. He notes:

Learning is difficult in conflict settings. NGO staff work in the context of urgency, have action-orientated working styles, and as a result often find it difficult to create time and space for reflection and learning. In conflict-torn societies, competition and distrust hamper knowledge sharing, and the context of knowledge itself is often contested. ${ }^{26}$

Focusing on the practitioner, Lederach, Neufeldt and Culbertson have identified five key merits to be gained from reflection on their practice, namely: helping projects and programs keep-up with unexpected events; promoting creative thinking and responses amongst staff and partners; providing opportunities to strengthen relationships and partnerships outside of finance-related visits; enhancing the relevance and effectiveness of programs; and providing opportunities to enhance organizational capacity and maximize limited staff and financial resources. ${ }^{27}$

Having worked in a variety of conflict-affected settings, Anderson and Olsen argue that peace practitioners do pay particular attention to the effectiveness of their interventions. However, they suggest that they should continually ask challenging, and perhaps uncomfortable, questions such as: How do we do what we do better, with more effect, with better effect? How do we know that the work we do for peace is worthwhile? What, in fact, are the results of our work for the people on whose behalf, or with whom, we work? ${ }^{28}$ A follow-on question might usefully be added, namely: How do we share this learning about the effectiveness of our work with wider audiences? In a Special Report by the United States Institute of Peace, Andrew Blum argues that "the effective evaluation of peacebuilding programs is essential if the field is to learn what constitutes effective and ineffective practice and to hold organizations accountable for using good practice and avoiding bad practice". ${ }^{29}$ For Wake et al the merit of documentation and evaluation is clear when they contend that "Evaluation and documentation of peacebuilding experiences, and communication among peacebuilders are, accordingly, essential to make certain that the lessons learned are widely 
available." 30 In the context of limited financial support for community-based peacebuilding work, this remains a real challenge. Reinmann and Ropers observe that "despite all rhetoric about the need for burden sharing many civil-society organizations still prioritize self-preservation over true and meaningful cooperation and coordination." 31

Internationally, it appears that the argument in favour of monitoring and evaluating peacekeeping and peacebuilding practice has already been won. ${ }^{32}$ Yet, for us, this focus overlooks the vital need to step back one stage to ensure that the actual methods and approaches used to build peace are accurately and effectively documented. The detailed and systematic documentation and dissemination of methodological practices from civil society interventions appears to be no more a priority internationally than it is in the Northern Ireland context. Lederach et al admit that while "innovative approaches have proven effective", they "could have great impact if they were more widely implemented or integrated with other projects or programmes." 33 The problem remains: how are we to learn what these innovative approaches might be? In what contexts do they work? What obstacles are faced and how are they overcome? It is the absence or accessibility of these materials in the public realm that further compounds the problem. In the context of evaluations, which might also detail the methodological practices involved in the intervention, Paffenholz notes that, while these might be robust and detailed, "most of them, however, are not publicly available." ${ }^{34}$ It is precisely the absence of publicly available, easily shareable and readily useable documentation of methods, practice and evaluation that leaves space for disparagement of many peacebuilding initiatives. Focusing on the Northern Ireland context, Power acknowledges a critique often levied at grassroots peacebuilding work. She notes that, as there is no common mode of assessment and measurement, "its usefulness will always be under question" ${ }^{35}$ and stresses the need to more clearly document, understand and contextualize the forms of peacebuilding which have taken place. This note of caution has been proven to have significant validity, based on the research findings of this study.

\section{What works? Evidence from Northern Ireland}

During the suspension of the nascent Northern Ireland Assembly in 2005, the Westminster government introduced a new policy framework which aimed to address the legacy of damaged relationships across and between communities in Northern Ireland. Known as the Shared Future document, among other things it highlighted and encouraged the documentation and sharing of good practice for the building of 'good relations' among divided communities. ${ }^{36}$ Never fully implemented, the re-established Assembly belatedly issued a more tentative and limited policy document for public consultation entitled Programme for Cohesion, Sharing and Integration. ${ }^{37}$ Widely criticized for its lack of detail and ambition, ${ }^{38}$ the responsible department took a further three years to issue a revised policy strategy. ${ }^{39}$ Consecutively, all three documents made 
two very similar points of observation. Firstly, the documents all recognized the quantity and quality of effort which has been directed at the building and rebuilding of relationships between the two main politically and ethnically divided communities both before, and since, the 1998 Agreement. Secondly, all three acknowledged the need to document and share 'good practice' or 'best practice' ${ }^{40}$ to support and progress the practice of addressing inter-communal division. Arguably, both issues continue to lack adequate attention and focus. While not the direct focus of this article, it is worth acknowledging that the disappointing and inconsistent efforts by the political elites to develop and implement public policy to address inter-communal division to date has significantly hampered the efforts made at grassroots-level to make significant change in this area.

While the majority of academic literature on the Northern Ireland conflict has focused on the political aspects of the peace process and its outworkings, the challenge of addressing the most significant ethnic/religious cleavage between the two main communities has also been explored and addressed. ${ }^{41}$ That said, within this important body of work, surprisingly few have ventured to document, in any detail, the precise methodological approaches adopted by those engaged in the building of relations at community level, the theories of change which influence their strategic interventions, or the demonstrable impact that they have had on the support and development of better relations between estranged communities. This study sought to further explore the extent to which the existing materials is available and accessible to those who might wish to learn from it, both locally and internationally and thus, explore the impact of the availability, or not, of such potential resources. Based on our initial, desk-based research, we identified three main categories of literature. Firstly, literature which includes examples and case studies of programmes and projects to address intercommunal division, in a variety of settings. Secondly, more practical 'how-to' manuals and guidance notes for those wishing to implement particular methodological approaches to improve relationships or support reconciliation processes. Thirdly, materials which have an evaluative element, that focus not only on the specifics of the methodological approaches, but also on the perceived outcomes of the practices themselves.

Despite an extensive trawl for materials including books, articles, research and project reports, little publicly available literature exists which documents the 'good practice' or 'best practice' approaches undertaken by community-based organisations. ${ }^{42}$ Two reports, separated by more than a decade, are exceptions. In 1993, the Community Relations Council commissioned a report entitled 'Building the Peace: Good Practice in Community Relations Work in Northern Ireland' ${ }^{43}$ which aimed to provide some support and guidance for those interested in 'the practical and constructive work of addressing the divisions' ${ }^{44}$ Interspersed within the report were brief references to a diverse range of projects and initiatives, with the focus of highlighting elements of good practice contained within them. One might question the utility of such brief descriptions to those practitioners wishing to emulate such good practice, either in-country or internationally, 
however, it was at attempt to fill an identified gap in information available. In 2006, eight examples of long-standing reconciliation-focused organisations in Northern Ireland were documented in a report entitled 'What Works for Reconciliation ? $^{45}$ The stated objective of the primary research was "to distil transferable 'good practice' from which other new, or improving, organisations might benefit". ${ }^{46}$ Interesting and informative, key insights into the practical, ethical and contextual challenges of relationship-building work were explored in comparative context. While both are useful contributions to the field, they highlight the work of only a small fraction of the thousands of projects which have been supported over the past decades and do little to provide the evidence to demonstrate the objective inclusion of some approaches over others in terms of effectiveness, impact or reach.

Other, mainly brief, 'good practice' case studies of organisations or projects were also identified. These are regularly included within annual reports, ${ }^{47}$ grant programme reports, ${ }^{48}$ policy documents, ${ }^{49}$ newsletters ${ }^{50}$ or on grantmaker websites ${ }^{51}$. However, these tend to be only brief summaries of the types of work which a grantmaker has funded, rather than detailed descriptions or evaluations of the approaches taken. For example, in their response to a government policy document, the Northern Ireland Community Relations Council (NICRC) included an Appendix entitled "Examples of models of Good Practice in Community Relations developed through CRC" ${ }^{52}$ Despite its title, it did not substantially detail the methodological approaches taken by initiatives or their efficacy, other than in very broad brush strokes. It was, therefore, unclear as to how the label of 'good practice' had been measured or applied. These brief descriptions are helpful contributions to the knowledge base, and serve as both pointers for further exploration, as well as demonstrating the breadth of work being undertaken and the diversity of approaches being supported. However, in order to be of practical benefit for a broader audience wishing to learn from, or replicate, methods and approaches adopted, they would require much greater investigation and analysis.

Materials related to the second category of literature- the 'how to' toolkits and manuals - were more readily identified. During some of the worst years of the ethno-political conflict, the NICRC published 'Community Conflict Skills: A Handbook for Groupwork in Northern Ireland', 53 addressing a significant gap in practical skills for those wishing to develop initiatives aimed at both intra- and inter-group conflict. Such was the need for practical, workable materials, it was republished in 1990 and again in 1995. Later, other training-type manuals were developed, focusing on diversity and difference, ${ }^{54}$ sectarianism and difference, ${ }^{55}$ schools, youth and reconciliation, ${ }^{56}$ community relations, ${ }^{57}$ and dealing with the past. ${ }^{58}$ Some resources act as stand-alone documents; others require pre-training before utilization or the skills of a facilitator to deliver the materials. Undoubtedly valuable sources of methodological approaches to address aspects of relationship-building for those who obtained them, such training manuals are often criticized for their short 'shelf-life' and limited dissemination opportunities. 
The accessibility of evaluations of programmes and interventions to support community relations work was particularly revealing. Some examples of evaluations which have been published and disseminated widely and successfully do exist and focus on a wide range of themes and approaches, including: the adoption of mobile phone technologies in contested areas, ${ }^{59}$ community-based restorative justice, ${ }^{60}$ sharing in education, ${ }^{61}$ the management of parades and bonfires as cultural expression, ${ }^{62}$ citizenship education, ${ }^{63}$ the building of relationship-building across interfaces and 'peace walls' in Belfast, ${ }^{64}$ communities in transition, ${ }^{65}$ community-based approaches to 'truth-telling' ${ }^{66}$ and the building of shared spaces within rural communities. ${ }^{67}$ These evaluations tend to be project rather than organisation focused and remains as standalone pieces which are not fully embedded into a strategic discussion about the activity and trajectory of relationship-building work within a wider context.

Despite the availability of some published assessments of community-relations focused interventions, we know that they represent only a small percentage of project and programme evaluations which are conducted on an annual basis in Northern Ireland. External evaluations are increasingly a compulsory component of funding programmes and are specifically budgeted into the programmatic costs. However, our research indicates that the majority of these documents are virtually inaccessible to those not directly involved in their commissioning or execution. Independent evaluators or assessors tend to pass their reports to the commissioning organization or funder for their internal usage, but rarely seek, or are given permission, to circulate more widely. This may speak to wider issues of ownership and the competitive field of private consultancy work which militates against the sharing of commissioned work. As it currently stands, the broad level of inaccessibility of this evaluative material serves only to limit our knowledge of what practices hold up to in-depth examination and scrunity, and which are fundamentally flawed in design or delivery.

\section{Uncovering Grey Materials}

In order to further explore the accessibility, or otherwise, of materials which would add to the corpus of knowledge of methodological approaches to addressing division, we undertook a focused study of a key grantmaking programme. ${ }^{68}$ This programme contributes towards the salary and running costs of a select number of organisations which are considered to be of 'strategic importance in promoting community relations in Northern Ireland'. ${ }^{69}$ In 2012, the programme awarded $£ 1.33$ million of government funding to twenty-seven voluntary and community organizations. Our motivation for this more detailed examination was three-fold. Firstly, to identify the types of information which grantee organisations typically document in terms of their theories of change, methodological approaches, outputs and outcomes. Secondly, to gain some insight into the types of information which funders tend to request, collect and collate from their grantees. Finally, it was hoped that this approach could serve as a preliminary assessment of the general accessibility of materials available for others interested in this field of intervention. It is, therefore, not to be assumed that particular judgments have 
been placed on the funder involved, the programmes and organisations supported, or their practices.

Primarily, the research sought to identify material that was compiled either by the organization itself or external evaluators as evidence of how they approach good relations activities. When contacted by the authors as part of the study, a number were willing and able to furnish us with internal training materials, team notes and reports and external evaluations of projects and programmes with which they were engaged. This was often with the proviso that these documents were to assist and inform the research, rather than for external circulation or citation. Others indicated that they did not have much substantive material to share beyond original grant applications and annual reports regarding specific details of their project design and delivery. Some organizations indicated that internal documentation did exist but were reticent to share it with the study. Only a small percentage of the organizations had examples of literature which was fully in the public domain, either in printed or web-based formats. During the process of requesting such information, it was clear that, while staff and board members could see the value in documenting, reflecting upon, and evaluating their practice, they did not, necessarily, have the time, resources or perceived skills required to undertake this task in any detailed or systematic manner.

This particular grant scheme has a well-established system for the collection of qualitative and quantitative data from the grantee organisations. Typically, this involves quarterly returns to the funder detailing how, and in what ways, objectives are being met. There is also a yearly report required of the grantees which outlines quantitative aspects of the programmes including numbers of participants and financial expenditure. Qualitative responses are minimized to bulleted responses of how programmatic objectives were met. In addition, regular evaluation visits with the funded organisations takes place to review progress against agreed objectives. This approach serves a number of distinct purposes. Firstly, to ensure the accountability and transparency of public funding. Secondly, to inform subsequent funding decisions for that particular grantmaker. Thirdly, to identify future funding priorities within the broader field. In addition, the grant programme convenes conferences, annual reviews, and practitioners' fora which act as networking and information-sharing opportunities for those engaged in community relations-focused activities. These are helpful if you are plugged in to such networks and supported by such funders, but are less so if you are new to such work, or are external to such contexts, wishing to learn from the Northern Ireland experience.

While the funding organization concerned clearly articulated the rationale for their reporting and evaluation mechanisms, some grantees questioned their value and identified limitations in this approach. Several organisations indicated that, in their view, the information requested for progress reports is often inadequate, if intended to be supportive and encouraging of meaningful reflective practice. It was also noted that, despite requirements to provide qualitative evidence of outputs and outcomes, the 
perceived lack of meaningful feedback from the funders resulted in feelings of frustration that the work being undertaken was not wholly appreciated or understood. The challenge for grantmakers is to ensure that the data collected through formal reporting mechanisms is substantive, constructive and meaningful. Adding a richness of the story from the work extends the relationship between the funder and funded organisation. Basing a relationship on mutual understanding and respect for the work being undertaken and challenges faced - and overcome - serves to enhance a cooperative culture and fostering transparency. For the groups and organisations who are involved in the practice of good relations, they will be incentivized by the knowledge that when they describe their activities fully to the funders they will be rewarded with feedback and recognition. For the funder, a deeper appreciation and understanding of the types of work, challenges, obstacles and rewards they are supporting can greatly enhance their ability to target effective initiatives and ensure good value for money and a return on investment.

Our research indicates that, despite wider calls for greater transparency and sharing of good practices, primary materials including applications, reports and evaluations, remain largely inaccessible as they are held internally and are not generally presented in accessible formats for wider usage. One might argue that this is unsurprising, given the potentially sensitive nature of much relationship-building work in conflictual context. It may not reflect any concerns which the funders' hold regarding the content of such materials - and indeed, some action plans and quarterly reports were provided to the study as evidence of the data submitted by organisations and programme. Rather that the information is collected in such a way as to require further contextualisation or analysis for it to be of use to those external to the processes described.

The benefits of greater emphasis and encouragement of qualitative documentation of practice to funders and great accessibility to, and analysis of, such internal documentation are not difficult to envision. For grant-awarding organisations and programme developers alike, a delicate balance has to be struck between the successful and efficient delivery of programmes and the effective documentation, monitoring, evaluation and sharing of learning emanating from such initiatives. There remains a tension between the level of information being requested by funders, versus their desire not to place too onerous a task on organisations to have to continually record or verify, rather than effectively deliver, their work. An additional tension was evident from our focused study: namely that, in an increasingly competitive field, qualitative reflection and sharing becomes a source of wariness for practitioners. They ask: Why share our good practice when we need to protect our jobs and funding from potential competitors in a contracting funding environment? What are the perceived benefits to our wider sharing of knowledge and lessons-learned and how can this be appropriately recognized or rewarded within the broader sector?

\section{Discussion}


Given the bedding in of the devolved, power-sharing political institutions in Northern Ireland, the changing priorities of external donors, and the economic downturn which has restricted public sector expenditure, is reasonable to assume that the levels of financial investment which have been directed towards the tackling of deep-rooted sectarianism within Northern Ireland will hardly be seen again. While a new tranche of dedicated 'peace and reconciliation' programme funding from the European Union is currently being negotiated, it will be much reduced in monetary terms. Other external donors have publicly stated their intention to withdraw from grantmaking in the region in the near future. ${ }^{70}$ The time to take stock of what has worked is long overdue.

Even before the more formal peace process, the region has been an important incubator for the development of innovative and creative approaches to transcend the deep divisions within the society and address negative attitudes towards 'the other'. And yet, our research has indicated that the evidence-base for knowing 'what works' in building good relations is surprisingly absent from documentation which is easily accessible to either the interested practitioner, policy maker or the general public. One might argue that, a place as small as Northern Ireland, it is not inconceivable that interested parties wishing to explore the value, efficacy and practical implementation of a particular initiative could identify the relevant individuals or organisations and approach them directly. However, this is hardly an efficient strategy for capturing learning and does not contribute to the international knowledge base for those other societies dealing with similar issues. While existing, publicly funded bodies plays an important role in supporting research, encouraging debate and discussion, and sharing good practice with varying degrees of formality, there is a need for a more structured and accessible repository of information, so that good practice can be captured and disseminated. The argument emerging from the broader field of peacebuilding is clear: in order to develop the field and ensure the most effective learning takes place from practices implemented, methodologies require documentation, and evaluations should be made publicly accessible and support transferability of lessons learned. Documenting methodologies, reporting challenges and encouraging a culture of self-reflection and evaluation requires an embedded practice which gets to the heart of the internal workings of such organisations. As Britton notes, 'Reflective practice involves the professional stepping back from an experience to make sense of it, understand what it means, learn from it and apply that learning to future situations' ${ }^{71}$

This highlights the key role that ongoing review and reflection has within a broader evaluation framework. Placing a value on the rigorous documentation and analysis on methodological approaches, and their impacts, allows for a much deeper and richer form of reflection which, in turn, allows for lessons-learned to be fully integrated, not only in organisational, but sector-wide practices. Linking appropriate, effective and efficient processes of reflection, monitoring and evaluation to any project or activity can allow for a full exploration of why, or why not, a particular methodology or approach had an intended impact. Moreover, the effective documentation of that learning can 
increase the cumulative or ripple effects within the field - and ultimately, the society as a whole. Such dissemination could greatly reduce the risk of duplication of ineffective methodologies and projects in a similar context and ensure progression, enhancement and greater effectiveness over time.

As in other contexts in receipt of substantial external donor intervention, monitoring and evaluation processes are commonly built in to the framework for programme delivery in Northern Ireland. The wider discourse on evaluation notes that such processes should go beyond a perception of inspection and audit which can embed mistrust and fear and should encourage a relationship where experiences are shared and choices made are examined, analysed and discussed in an honest and transparent learning environment. In this context, this means that a grantmaker can act, not only as a distributor of funds, but as a so-called 'critical friend' who challenges and encourages projects and organisations to continually reflect on their methodological approaches, and associated impacts. If, as Springett notes: "Evaluation is about collecting information to inform action", 72 evaluation must be embedded in the life cycle of the project, in order to ensure both formative and summative learning is possible. Our research indicates that, while funded projects and organisations may find it a somewhat onerous task to complete regular reports to funding bodies, all of those consulted recognized not only the responsibility they have to do so, but also the potential opportunity to make this a more meaningful experience. Organisations we engaged with spoke of an inherent value in being required to respond to challenging or creatively posed questions about their approach, methodologies and impacts. But, more than that, they highlighted the desire for regular, qualitative and substantive feedback from the funders in a systematic manner to ensure that both parties fully understand their respective roles and expectations.

A further insight of this discrete study is that further scope may exist, at an administrative level, to ensure that evaluations conducted on programmes or projects (either internally conducted or externally commissioned) are thoroughly considered and reviewed, that specific and general lessons are drawn from the findings and recommendations, and that they are seen to truly inform and influence any further iterations or developments of programmes in the future. While this may be the ambition of funding organisations, the fruits of internal labours to achieve such an objective may not be as obvious or embedded in the broader sectoral discourses and developments as they might be. The reasons for this are manifold, including lack of time and resources, poor dissemination strategies or changes in funding priorities. All too often, the lessons learned fail to be fully documented into easily accessible models of good practice, resulting in a loss of wisdom, expertise and learning which can be usefully and effectively transposed to other situations and contexts. There would be much value in the secondary analysis of the reports, applications and evaluations associated with such grant programmes, but there remains an issue of access, and of the quality of such documentary evidence, if this is to be a viable suggestion. The current value of internal monitoring and evaluation is clear and indications have emerged that a significant 
primary source of information housed by funders and does evaluators exist. Tapping into this resource and identifying key trends, methods and insights could not only provide a rich source of information to existing and potential practitioners, but could provoke new debate within the sector as to the effectiveness of particular approaches and the re-examination and refinement of practice.

In the Northern Ireland context, all evidence points to the outstanding issues which remain in addressing the levels of mistrust and suspicion between, and within, the two dominant communities. International examples of inter-ethnic tensions in Sri Lanka, the Balkans, Nigeria, Turkey, and most recently in Syria and Iraq indicate that urgent need to further understand and address the chasms which form between communities for the sake of local and regional stability. The demands on the international donor community to resource this grassroots-focused work, and the work-load for local peacebuilding practitioners, show little sign of diminishing. Therefore, it remains crucial that a more effective understanding of what has worked to date is developed, so that the methodologies used to guide continued engagement are based on considered reflection of past practice as well as being driven by the continually changing demands of a society which continues to grapple with the legacy of its violent past. As this article has outlined, the accessibility of existing academic and policy literature on methodologies and practices indicates that this is an emerging, yet underdeveloped field. This case study of Northern Ireland confirms that much can be learned from the work of organisations committed to promoting good relations between ethnically divided communities, yet too often documentation, evaluation and sharing approaches and practice has been subordinated, overlooked, or are relatively inaccessible. As a result, valuable learning is lost and opportunities for growth and development of the field may well have been hindered. 
${ }^{1}$ UN Secretary General, 'In Larger Freedom: Towards Development, Security and Human Rights for All', UN doc., A/59/2005, p.31.

${ }^{2}$ Karl DeRouen and Jacob Bercovitch, 'Enduring internal rivalries: A new framework for the study of civil war', Journal of Peace Research, Vol. 45, No.1, 2008, pp.43-62; Roy Licklider, 'The Consequences of Negotiated Settlements in Civil Wars, 1945-1993', The American Political Science Review, Vol.89, No.3, 1995, pp.681-693; Edward Luttwak, 'Give war a chance', Foreign Affairs, Vol.78, No.4, 1999, pp.36-44.

${ }^{3}$ Severine Autesserre, 'Going Micro: Emerging and Future Peacekeeping Research', International Peacekeeping, Vol. 21, No. 4, 2014, pp.492-500.

${ }^{4}$ Jonny Byrne, Cathy Gormley-Heenan, and Gillian Robinson, Attitudes to Peace Walls, Belfast: OFMDFM, 2012.

${ }^{5}$ Ulf Hansson, Una O'Connor Bones and John McCord. Integrated education: A review of policy and research evidence 1999-2012, Belfast: Integrated Education Fund, 2013. ${ }^{6}$ Paul Nolan, Peace Monitoring Report 2013, Belfast : NICRC, 2013.

${ }^{7}$ Dominic Bryan and Clifford Stevenson, 'Flagging Peace: Struggles over Symbolic Landscape in the New Northern Ireland' in: Culture and Belonging in Divided Societies: Contestation and Symbolic Landscapes. Ross, Marc Howard (ed.), University of Pennsylvania Press, 2009.

${ }^{8}$ Nolan (see n.6 above), p.143.

${ }^{9}$ Sandra Buchanan, 'Transforming Conflict in Northern Ireland and the Border Counties: Some Lessons from the Peace Programmes on Valuing Participative Democracy', Irish Political Studies, Vol.23, No.3, 2008, pp.387-409.

${ }^{10}$ International Fund for Ireland, Annual Report and Accounts 2005, Belfast: International Fund for Ireland, 2006, p.5; Deloitte, External Review for the International Fund for Ireland, Belfast: International Fund for Ireland, 2010, p.20.

${ }^{11}$ Northern Ireland Community Relations Council, Northern Ireland Community Relations Council Annual Report and Accounts for the year ended 31 March 2013, NICRC: Belfast, 2014.

${ }^{12}$ Maria Power (ed.), Building Peace in Northern Ireland, Liverpool: Liverpool University Press, 2011, p.10.

${ }^{13}$ Mary B. Anderson and Lars Olsen, Confronting War: Critical Lessons for Peace Practitioners: Reflecting on Peace Practice Project. Cambridge, MA: Collaborative for Development Action, 2003. p.10.

${ }^{14}$ Ibid, p.10.

${ }^{15}$ Grainne Kelly, Progressing Good Relations and Reconciliation in Post-Agreement Northern Ireland. Derry/Londonderry: INCORE, 2012.

${ }^{16}$ John Paul Lederach, Building sustainable peace: sustainable reconciliation in divided societies. Washington, DC: USIP, 1997, p.39.

${ }^{17}$ Ibid, p.43.

${ }^{18}$ Thania Paffenholz, 'International peacebuilding goes local: analysing Lederach's conflict transformation theory and its ambivalent encounter with 20 years of practice', Peacebuilding, Vol. 2, No. 1, 2013, pp.11-27. 
${ }^{19}$ Thania Paffenholz, Civil Society and Peacebuilding: A Critical Assessment, Boulder, CO: Lynne Rienner Publishers Inc, 2010, p.43.

${ }^{20}$ Ibid, p.48.

${ }^{21}$ Amy L. Smith and David Smock, Managing a mediation process, United States Institute of Peace, Washington, 2008.

${ }^{22}$ Marc Howard Ross, Action Evaluation in the Theory and Practice of Conflict Resolution, Bryn Mawr, PA: Bryn Mawr College, 2000; Anneke Galama and Paul van Tongeren (eds.), Towards Better Peacebuilding Practice. On Lessons Learned, Evaluation Practices and Aid \& Conflict, Utrecht: European Centre for Conflict Prevention, 2002; Alex Austin, Martina Fischer and Oliver Wils (Eds.), Peace and Conflict Impact Assessment: Critical Views on Theory and Practice, Berghof Handbook Dialogue No. 1, Berlin: Berghof Research Center, 2003; Cheyanne Church and Julie Shouldice, The Evaluation of Conflict Resolution Interventions. Part I and II, Londonderry: INCORE, 2002/03; CDA - Collaborative Learning Projects, Reflecting on Peace Practice Consultation Report: Understanding Cumulative Impacts, Boston, Mass.: CDA, 2008; Susanna P. Campbell, 'When Process Matters: The Potential Implications of Organizational Learning for Peacebuilding Success', Journal of Peacebuilding and Development Vol.4, no.2, 2008, pp.20-32.

${ }^{23}$ Carol H. Weiss, 'Nothing as Practical as Good Theory: Exploring Theory-based Evaluation for Comprehensive Community Initiatives for Children and Families', in James P. Connel I, Anne C. Kubisch, Lisbeth B. Schorr and Carol H. Weiss (eds.), New Approaches to Evaluating Community Initiatives: Concepts, Methods, and Contexts, Washington, DC: Aspen Institute, 1995.

${ }^{24}$ James P. Connell and Anne C. Kubisch, Applying a Theory of Change Approach to the Evaluation of Comprehensive Community Initiatives: Progress, Prospects, and Problems, Washington DC: Aspen Institute, 1998, p.2.

${ }^{25}$ Ken Menkhaus, Impact Assessment in Post-Conflict Peacebuilding: Challenges and Future Directions, Geneva: Interpeace, 2004, p.5.

${ }^{26}$ Willemijn Verkoren, The Owl and the Dove: Knowledge Strategies to Improve the Peacebuilding Practice of Local Non-Governmental Organisations, Amsterdam: Amsterdam University Press, 2008, p.21.

27 John Paul Lederach, Reina Neufeldt and Hal Culbertson, Reflective Peacebuilding: A Planning, Monitoring and Learning Toolkit, Notre Dame and Catholic Relief Services, 2007, p.51.

${ }^{28}$ Anderson and Olsen, (see n.13 above), p.10

${ }^{29}$ Andrew Blum, Improving Peacebuilding Evaluation: A Whole-of-Field Approach, Special Report Washington, DC: USIP, 2011, p.1.

${ }^{30} \mathrm{Jim}$ Wake, Juliette Verhoeven, and Paul van Tongeren, 'Introduction' in Paul van Tongeren, Malin Brenk, Marte Hellema, and Juliette Verhoeven, People Building Peace II: Successful Stories of Civil Society, London: Lynne Rienner Publishers, Inc, 2005, p.5.

${ }^{31}$ Cordula Reimann and Norbert Roper, 'Discourses on Peace Practices: Learning to Change by Learning from Change?' in Paul van Tongeren, Malin Brenk, Marte Hellema, Juliette Verhoeven, eds. People Building Peace II: Successful Stories of Civil Society, London: Lynne Rienner Publishers, Inc., 2005, p.11.

${ }^{32}$ Cheyanne Church, and M. Rogers, 'Designing for Results: Integrating Monitoring and Evaluation in Conflict Transformation Programs, Search for Common Ground', Washington, DC: Search for Common Ground, 2006; Megan G. Kennedy-Chouane, 'Improving conflict prevention and peacebuilding assistance through evaluation', OECD Journal: General Papers, Volume 2010/1, OECD, Paris, 25 May, 1011, pp.99-107; OECD and CDA Collaborative Learning Projects, Encouraging Effective Evaluation of Conflict Prevention and Peacebuilding Activities: Towards 
DAC Guidance, consultative report prepared for the OECD DAC Network on Development Evaluation and the DAC Network on Conflict, Peace and Development Co-operation, Paris: OECD, 2007; Thania Paffenholz and Luc Reychler, Aid for Peace: A Guide to Planning and Evaluation for Conflict Zones, Baden-Baden: Nomos, 2007; Dan Smith, Towards a Strategic Framework for Peacebuilding: Getting Their Act Together, Overview Report of the Joint Utstein Study on Peacebuilding, Ministry of Foreign Affairs, Oslo, 2004; United Nations, Monitoring Peace Consolidation- United Nations Practitioners' Guide to Benchmarking, United Nations, New York, 2010; Wake et al, 2005, (see n.30 above).

${ }^{33}$ Lederach, 2007, (see n.16 above), p.51.

${ }^{34}$ Paffenholz, 2010, (see n18. Above), p. 58.

${ }^{35}$ Power, 2011, (see n. 12)above, p.10.

${ }^{36}$ OFMDFM, A Shared Future - Improving Relations in Northern Ireland: the policy and strategic framework for good relations in Northern Ireland, Belfast: OFMDFM, 2005, p.65.

${ }^{37}$ OFMDFM, Programme for Cohesion, Sharing and Integration Consultation Document, Belfast: OFMDFM, 2010.

${ }^{38}$ Jennifer Todd and Joseph Ruane, From 'A Shared Future' to 'Cohesion, Sharing and Integration: An analysis of Northern Ireland's Policy Framework Documents, London: Joseph Rowntree Charitable Trust, 2010; Platform for Change, Cohesion Policy Challenged: Open Letter to OFMDFM, 2010 (at: platformforchange.net/wp-content/plugins/downloadattachments/includes/download.php?id=85 Accessed on 1 May 2014); Northern Ireland Community Relations Council, Towards a Shared Society? Community Relations Council response to the consultation on the Programme for Cohesion, Sharing and Integration, NICRC: Belfast, 2011; Colin Knox, 'Cohesion, sharing, and integration in Northern Ireland', Environment and Planning C: Government and Policy Vol.29, No.3, 2011, 548 - 566.

${ }^{39}$ OFMDFM, Together: Building a United Community. Belfast: OFMDFM,2013.

${ }^{40}$ OFMDFM, 2005, (see N.35 above) p.52; OFMDFM, 2010, (see N.36 above, p.8); OFMDFM, 2013, (see N.38 above), p.43.

${ }^{41}$ John Darby, Scorpions in a Bottle: Conflicting Cultures in Northern Ireland. London: Minority Rights Publications, 1997; Feargal Cochrane and Seamus Dunn, People Power?: The Role of the Community and Voluntary Sector in the Northern Ireland Conflict, Cork: Cork University Press, 2002; Norman Porter, The Elusive Quest: Reconciliation in Northern Ireland. Blackstaff Press, Belfast, 2003; Miles Hewstone, Nicole Tausch, Joanne Hughes, and Ed Cairns, Can contact promote better relations? Evidence from mixed and segregated areas of Belfast. Belfast: OFMDFM, 2008; Alice Clancy and John Nagle, Shared Society or Benign Apartheid? Understanding Peacebuilding in Divided Societies, London: Palgrave Macmillan, 2010.

${ }^{42}$ As well as the traditional bibliographic and journal article searches, the extensive publications repositories of the Community Relations Council (at: www.communityrelations.org.uk/services/publications/), the ARK Northern Ireland Qualitative Archive (at: www.ark.ac.uk/qual/conflict/) and the ARK Social Policy Research Database (at: www.ark.ac.uk/orb/Socialdb.html) were reviewed in order to capture documents published not only within an academic, but also a wider research and practice setting.

${ }^{43}$ John Lampen, Building the Peace: Good Practice in Community Relations Work in Northern Ireland, Belfast: Community Relations Council, 1995.

${ }^{44}$ Ibid, 1995, p.ii.

${ }^{45}$ Robin Wilson, What works for reconciliation? Belfast: Democratic Dialogue, 2006.

${ }^{46}$ Ibid, 2006, p.5. 
${ }^{47}$ Atlantic Philanthropies, 2008 Annual Report, New York: Atlantic Philanthropies, 2008; Atlantic Philanthropies, Giving While Living, New York: Atlantic Philanthropies, 2012; SEUPB, Special EU Programmes Body Annual Report 2012, Belfast: SEUPB, 2012; Community Foundation Northern Ireland, Realising Potential. Inspiring Communities. Community Foundation Annual Report 201213, Belfast: CFNI, 2013.

${ }^{48}$ International Fund for Ireland, Effective Peacebuilding. Belfast: International Fund for Ireland, 2010 (at: www.internationalfundforireland.com/effective-peace-building); Community Foundation for Northern Ireland, A Summary of Good Practice among Victims and Survivors' Groups. Belfast: CFNI, 2003; Community Foundation for Northern Ireland, A Model for Peacebuilding and Working Together: Reflections from the Communities in Transition Programme. Belfast: CFNI, 2012 (at: www.communityfoundationni.org/download/files/CIT\%20In\%20Brief\%20-

\%20Model\%20for\%20Peacebuilding.pdf

${ }^{49}$ OFMDFM, 2010 (see n.36 above).

${ }^{50}$ See, for example, the Special EU Programmes Body quarterly newsletter (at: www.seupb.eu/NewsAndEvents/youreu/yourEUarchive.aspx).

${ }^{51}$ See, for example, Atlantic Philanthropies (at: www.atlanticphilanthropies.org/rhr-northernireland); SEUPB Project Case Studies, (at: www.seupb.eu/media/Project_Case_Studies.aspx)

${ }^{52}$ Northern Ireland Community Relations Council, 2011, (see n.37 above), pp.65-70.

${ }^{53}$ Mari Fitzduff, Community Conflict Skills: A Handbook for Anti-Sectarian Work in Northern Ireland, Cookstown, Co. Tyrone: Community Conflict Skills Project, 1988.

${ }^{54}$ WEA, Us and Them (I\&II) Belfast: Workers' Educational Association, 1995.

${ }^{55}$ Yvonne Naylor, Moving Beyond Sectarianism: A Resource for Young Adults, Youth and Schools. Belfast: Irish School of Ecumenics, 2001; Yvonne Naylor, Who We Are-Dealing with Difference Resource Pack: A resource for teachers, leaders and children 9-14, Belfast: Irish School of Ecumenics, 2003; Trevor Williams, Margaret McGovern, and Cathy Curran, Creating Community, Belfast: Corrymeela Community, 2001.

${ }^{56}$ The Boys' Brigade in Northern Ireland, Investing in our Future, Belfast: The Boys' Brigade, 2001; Mary Potter and Nichola Lynagh, Joined-up: Developing Good Relations in the School Community, Belfast: Corrymeela/NICIE, 2005; CCEA, Living.Learning.Together: Personal Development and Mutual Understanding, Belfast: CCEA, 2006.

${ }^{57}$ Northern Ireland Community Relations Council, What Can We Do?: A Practical Guide to Community Relations in Northern Ireland, NICRC: Belfast, 1993; Duncan Morrow and Derick Wilson, Ways out of Conflict - Resources for Community Relations Work, Coleraine: The Understanding Conflict Trust, 1996.

${ }^{58}$ Liam O'Hagan (ed.) Stories in Conflict: Towards Understanding and Healing, Derry: Yes! Publications, 2008; Healing Through Remembering, Conversation Guide on Dealing with the Past, Belfast: Healing through Remembering, 2009.

${ }^{59}$ Michael Hamilton, Working Relationships: An Evaluation of Community Mobile Phone Networks in Northern Ireland, Belfast: NICRC, 2001.

${ }^{60}$ Harry Mika, Community Based Restorative Justice in Northern Ireland, Belfast: Queen's University Belfast, 2006.

${ }^{61}$ Tony Gallagher, Alistair Stewart, Richard Walker, Mark Baker and Jacqueline Lockhart, 'Education through schools working together' in Shared Space, Issue 10, Belfast: NICRC, 2010, pp.65-74; Education and Training Inspectorate, A Final Evaluation of the International Fund for Ireland's Sharing in Education Programme, Belfast: ETI, 2013. 
${ }^{62}$ Jonny Byrne, 'Interface violence in East Belfast during 2002: The mechanisms and programmes employed to limit the impact on local residents' Shared Space, Belfast: NICRC, 2006, pp.15-26; Byrne, Evaluation of Belfast City Council Bonfire Management Programme 2007, Belfast: Belfast City Council, 2007; Byrne, Evaluation of Belfast City Council's Bonfire Management Programme 2008, Belfast: Belfast City Council, 2008; Byrne, Evaluation of Belfast City Council's Bonfire Management Programme 2011, Belfast: Belfast City Council, 2011; Byrne, Jonny, and Olivia O'Riordan, Review of the Belfast City Councils Bonfire Management Programme 2007-2009, Belfast: Institute for Conflict Research, 2009; Neil Jarman, Mary-Kathryn Rallings, and John Bell, Local Accommodation: Effective Practice in Responding to Disputes over Parades, Belfast: Institute for Conflict Research, 2009.

${ }^{63}$ Institute for Conflict Research, Belfast Citizenship Education Programme, Belfast: Institute for Conflict Research, 2011.

${ }^{64}$ Neil Jarman, Working at the Interface: Good Practice in Reducing Tension and Violence, Belfast: Institute for Conflict Research, 2006; Roz Goldie and Brid Ruddy, Crossing the Line: Key features of effective practice in the development of shared space in areas close to an interface, Belfast: Belfast Interface Project, 2010.

${ }^{65}$ Community Foundation Northern Ireland, The Communities in Transitions Programme: Policy and Practice Lessons, Belfast: CFNI, 2008.

${ }^{66}$ Patricia Lundy and Mark McGovern 'Community-based Approaches to Post-Conflict 'Truthtelling': Strengths and Limitations', Shared Space, Issue 1, Belfast: NICRC, 2005, pp.35-52.

${ }^{67}$ Rural Community Network, Rural Community Estates Programme: Practice to Policy Study, Cookstown: Rural Community Network, 2007.

${ }^{68}$ The Northern Ireland Community Relations Council Core Funding Grant Scheme. For more information, see www.community-relations.org.uk/funding-posts/media-grant-scheme/

Accessed 1 May 2014.

${ }^{69}$ Northern Ireland Community Relations Council, Core Funding Programme 2014 - 2015:

Programme Criteria and Guidance Notes. (at: www.community-relations.org.uk/wpcontent/uploads/2013/11/CFP\%20Guidance\%20notes.doc Accessed on 1 May 2014).

${ }^{70}$ See www.atlanticphilanthropies.org/fall10-letter-intro and www.internationalfundforireland.com/images/stories/documents/Strategic_Framework/ifi_stra tegic_framework_for_action.pdf

${ }^{71}$ Bruce Britton, 'Self Reflection' Capacity Development in Practice, edited by Jan Ubels, Naa-Aku Acquaye-Baddoo, Alan Fowler, London: Earthscan LLC., 2010, p.269

72 Jane Springett, 'Appropriate approaches to the evaluation of health promotion', Critical Public Health, Vol. 11, No.2, 2001, pp.139-51. 